\title{
セメントモルタルの半透過性に起因する浸透圧の測定 MEASUREMENT OF OSMOTIC PRESSURE INDUCED BY SEMI-PERMEABILITY OF CEMENT MORTAR
}

\author{
田中享二*1, 裴 基 善*2, 湯 浅 昇*3 \\ Kyoji TANAKA, Keesun BAE and Noboru YUASA
}

\begin{abstract}
Osmotic pressure induced by semi-permeability of hardened cement mortar was studied. The apparatus composed of the two cells, one of which is filled with $\mathrm{NaCl}$ solution of $2 \mathrm{~mol}$ and the other is filled with distilled water, was developed to measure osmotic pressure. Mortar disks of three levels of thickness from 5 to $15 \mathrm{~mm}$ were adopted as test specimens, and osmotic pressure, water permeability and ion movement were measured at $30^{\circ} \mathrm{C}$ for the specimens with water cement ratios such as 45,60 and $75 \%$.

The following results were obtained.

1. Osmotic pressure is basically affected by movability of water, $\mathrm{Na}^{+}$and $\mathrm{Cl}^{-} \mathrm{Ion}$ in cement mortar,and maximum osmotic pressure, $1.2 \mathrm{MPa}$ was observed.

2. Hardened cement mortar may be considered as semi-permeable material with low reflection coefficient.
\end{abstract}

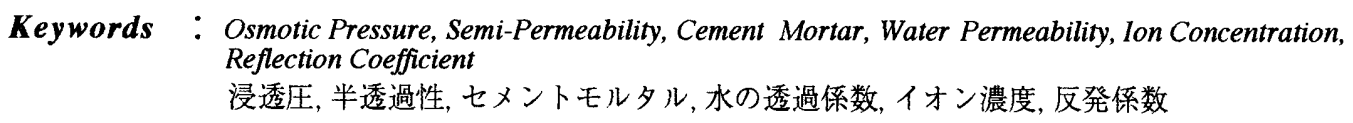

\section{1.はしめに}

セメント硬化体は nmから $\mathbf{m m}$ オーダーまでの広い範囲の細孔をも つ多孔体 1,2) である。そのため、水を透過させる。しかし、水に 比べ、溶質、イオン等に対しては通しにくい性質を持つといわれて いる。もちろんセメント硬化体は細孔径や、その分布を完全に制御 された工業製品ではないため、半透過膜的性質といっても完全なも のではない。しかしその性質のため、結果として浸透圧が生じ。 この浸透圧はアルカリ骨材反応によるコンクリート破壊の原因 ${ }^{3)}$ 、 あるいは最近問題化しているコンクリート下地に施工された塗床 材、塗材などの仕上げ材の剥離、ふくれの原因の一つであり ${ }^{4)}$ こ れらの欠陥を未然に防ぐためにも、セメント硬化体のもつ半透過性 的な性質の解明は重要である。

これに関連する既往の研究についてであるが、古くはアルカリ骨 材反応に関連して検討が始められた。Hansen ${ }^{5)}$ は、アルカリ骨材反 応による膨張破壊機構の基本は、浸透圧によるとし、セメント硬化 体を初めて半透過性をもつ物質としてとらえた。また、これに関連 してD.McConnell $5^{6)}$ は、蒸留水側からモル夕ルを介して、ケイ酸 ナトリウム側に移動してくる水により上昇する圧力について述べて いる。一方仕上げ材との関連ではW. J.Warlow ら 発生の原因をセメント硬化体の半透過性に求め、セメントペースト
やモルタルが半透過性をもつことを示した。さらに M. Günter $ら^{8)}$ は、仕上げ材料より溶出される水溶液を用いて実際に浸透圧を測定

し、これがふくれの駆動力であることの可能性を示した。

しかしながらこれらの研究では、セメント硬化体の半透過性を確 認し、それが浸透圧を発生させる原因について類推しているに過ぎ ず、どの程度の半透過性をもつのか、セメント硬化体のどのような 性質と関係するのかといった面からの検討が十分ではない。本研究 はそれらを明らかにすることを目的とし、その第一段階としてセメ ントモルタルを例として、これらの材料の半透過膜的性質について 評価検討したものである。

\section{2. 実験の概要}

\section{1 試験体}

試験のための試料には骨材を加えないセメントペーストを用いる ことが望ましいが、予備実験の結果、幅広い水セメント比の領域で 均質な試験体を作ることが難しいこと、また余り厚くすると水の浸 透に時間がかかりすぎること、また逆に薄くすると生じた圧力によ り試験体自身が破損する等の、実験上の困難があることが判明した ため、比較的安定して測定が可能なモルタル試験体を使用すること とした。試験体の水セメント比は45,60および75\%の3種類であり、
*1 東京工業大学建築物理研究センター 助教授・工博

*2 東京工業大学 大学院生. 工修

*3 日本大学生産工学部 助手. 工修
Assoc. Prof., Structural Engineering Research Center, Tokyo Institute of Technology, Dr. Eng.

Graduate School, Tokyo Institute of Technology, M. Eng.

Research Associate, College of Industial Technology, Nihon University, M. Eng. 
その調合を表-にに示す。ブリージングによる試験体の不均一きを低 減させるため、水セメント比が大きくなるほど、砂セメント比の高 くなる調合とした。なお試験体の厚さは5,10および $15 \mathrm{~mm}$ の3段階と した。試験体の作製は、直径 $100 \mathrm{~mm} \phi$ 、各試験体の厚さより各々 $5 \mathrm{~mm}$ ずつ大きい 10,15 おび20 $\mathrm{mm}$ の型枠に所定のモルタルを打ち込 み、2日間密封養生 $\left(20^{\circ} \mathrm{C}, 100 \%\right.$ R.H 環境 $)$ 後、表面を研磨し、その

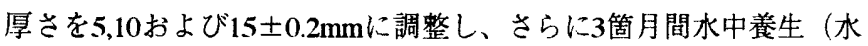

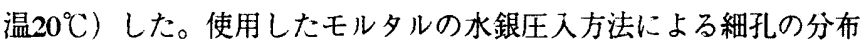
を図-1に示す。

2.2 使用溶液

浸透現象を生じさせるための溶液は、取扱いに危険の少ない $\mathrm{NaCl}$ 溶液とイオン交換された蒸留水とした。なお浸透圧は溶液濃 度の影響を受けるが、ここでは浸透現象を顕著に生じきせるため比 較的高い濃度の $2 \mathrm{~mol} / \ell$ の $\mathrm{NaCl}$ 溶液を使用した。

\section{3 試験装置}

浸透圧測定装置を図-2に示す。試験体を中心として、一方の側に 蒸留水を入れたアクリル製のI 側容器、もう一方の㑡に NaCl溶液 を入れた真鍮製の II 側酎圧容器（各々の内径 $70 \mathrm{~mm} \phi$ 、奥行き $60 \mathrm{~mm}$ ）を設置した。II 側は閉鎖空間となっているため、内部圧力が上昇 するが、その内壁には压力測定のための圧力変換器（共和電業 PGM-20KE、最大容量2MPa）を取り付けた。

試験体は両容器に○リング、シリコーンシーリング材を用いて固 定されるが、厚さ $5 \mathrm{~mm}$ の試験体の場合は压力上舁に伴う曲げ破損を 防止するため、試験体の蒸留水側に嫄さ $5 \mathrm{~mm}$ の真鍮製の孔の多数あ けられた補強板を取り付けて測定した。

\section{4 実験の方法}

いくつかの予備実験の結果、試験装置の組立後值ちに測定を開始 すると、試験体の微細空隙への吸水のためと推定されるが、【I 側の $\mathrm{NaCl}$ 溶液側容器内压力の負の状態がしばらく観測されることが判 明した。この負圧の期間は浸透压発生の前段階の期間であると考え られる。そのため測定時間短縮を目的とし、以下に示す前操作を 行った。まず両容器に蒸留水を入れ、【I側のコックを開放した状態 でII 側から低圧（0.08MPa 程度）の水王を1日負荷する。ついでI 側の蒸留水を $2 \mathrm{~mol} の \mathrm{NaCl}$ 液で入れ替え、また I 側から同程度の圧 力を1日負荷する。その後圧力を解除し、I 側に新たな蒸留水を入 れ、浸透圧の測定を開始した。測定は圧力上昇が鈍化し、注は定圧 状態になるまで行った。

\section{3. 測定結果}

図-3に浸透圧の測定結果を示す。試験体によるばらつきが多少見 られるが、測定開始後しばらくの闌、浸透王は汪泟直線的に上昇 し、次第に変化が少なくなり、その後は活浬一䇥の值となる。

浸透圧の上舁状況はモルタルの水セメント比および試験体の厚导 の影響を強く受ける。すなわち、水セメント比については、図-4に 浸透压の最大值と水セメント比の関係を示すように、45\%および 60\%の場命が75\%よりかなり大きな漫透压を示している。ただし、 45\%と60\%の閒ではその差は少なかった。試験体の厚导の影響につ いては、図-5に漫透圧の最大值と試験体の曆さとの関係を示すが、

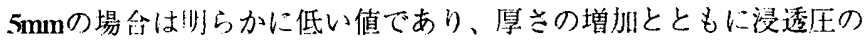
值は上昇すっ，ただし、厭さ $1.5 \mathrm{~mm}$ で浸透巨が低下する傾向のもの
表-1 セメントモルタルの調合（贒量比）

\begin{tabular}{|c|c|c|}
\hline $\begin{array}{c}\text { 水セメント比 } \\
(\%)\end{array}$ & $\begin{array}{c}\text { 砂セメント比 } \\
(\mathrm{S} / \mathrm{C})\end{array}$ & $\begin{array}{c}\text { フロー値 } \\
(\mathrm{mm})\end{array}$ \\
\hline 45 & 1.3 & 170 \\
\hline 60 & 1.7 & 210 \\
\hline 75 & 2.0 & 240 \\
\hline
\end{tabular}

* セメント：普通ポルトランドセメント（比重：3.16）

* 細骨材：絶乾比重2.27、吸水率 0.54 の豊浦標準砂

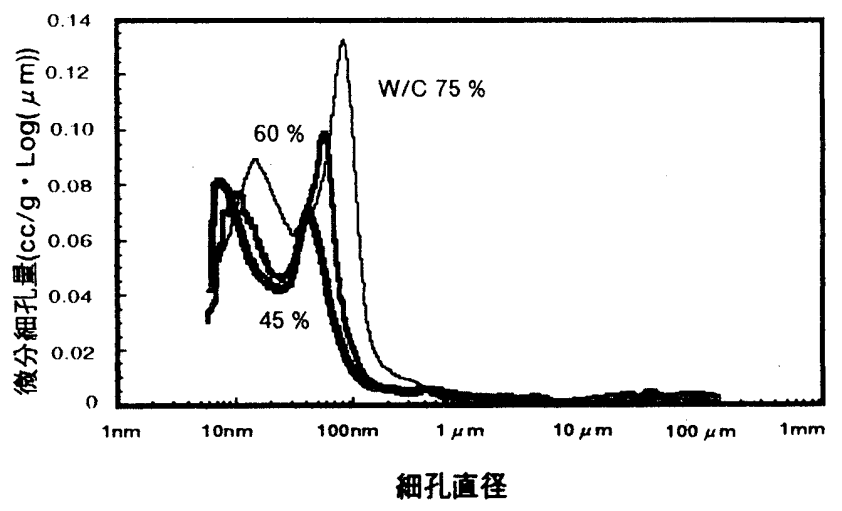

図-1 試験体の細孔分布の測定結果

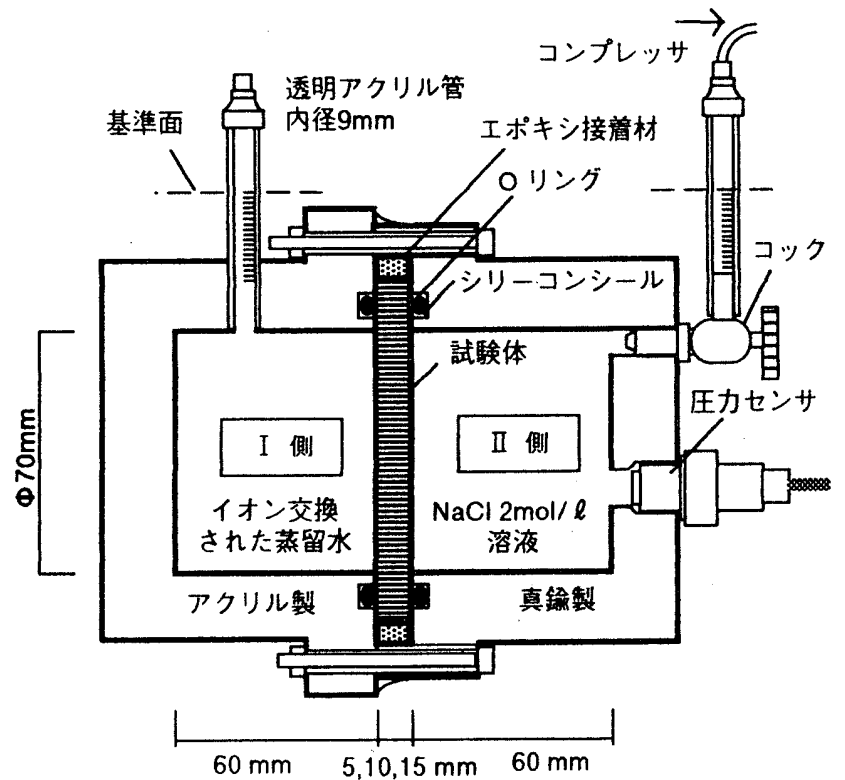

図-2 浸透圧測定装置

もあり、少し䘽雑な結果が得られている。

\section{4. 絓果の考察}

浸透圧の発現は、モルタルにより分けられた 2 相の溶液の化学ボ テンシャルの差と、溶媒である水を透過させ溶質であるNaおよび のイオンを透過きせにくい性質、いわ功万選択透過性によると考え られる。ここではその観点から考祭する。

図-6に浸透化測定終了直後のI側のNaおよびCイオン濃度の測定 

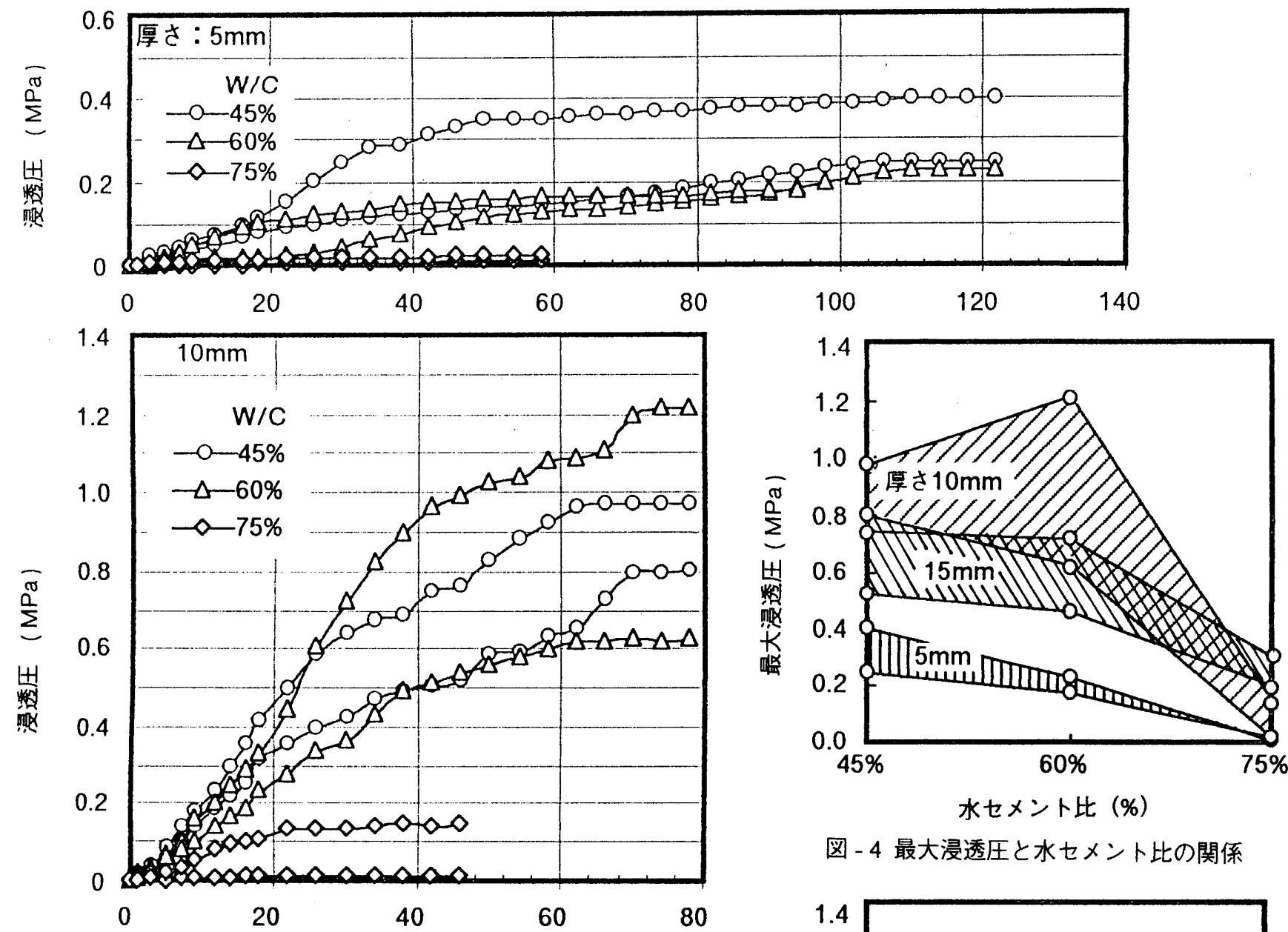

図 - 4 最大浸透圧と水セメント比の関係

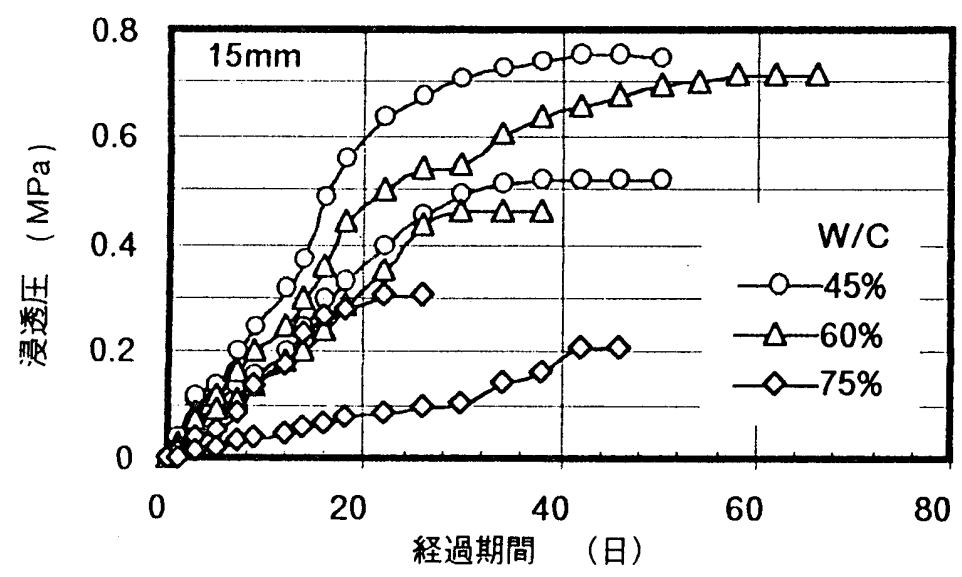

図 -3 浸透圧の測定結果

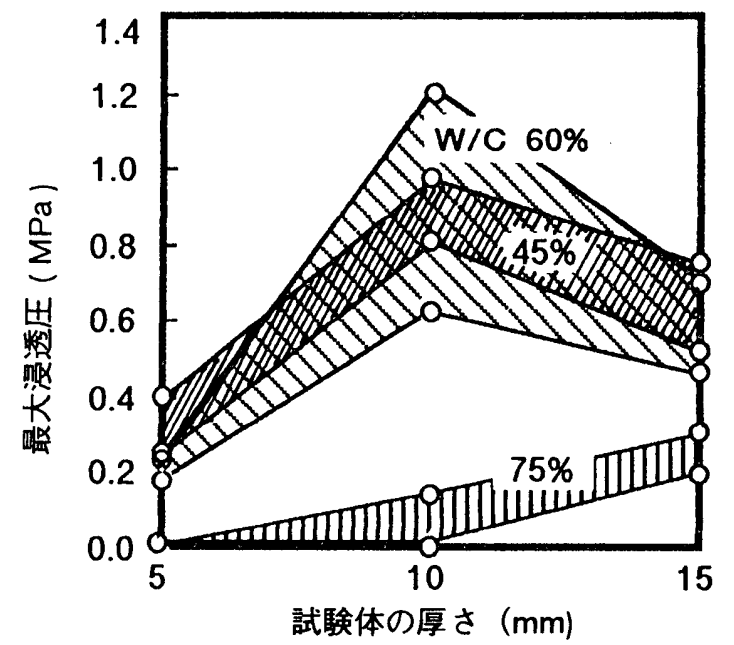

図 - 5 最大浸透圧と試験体の厚さの関係

結果を浸透圧との関係で示す。試験体によってばらつきも大きい が、水セメント比が低いほど、あるいは試験体が厚いほどイオン濃 度は低く、概ね I 側のイオン濃度が低い場合に浸透圧が高くなる傾 向が兒られている。イオン濃度が低いということは、イオンの動き が阻止されていることを意味し、このことはモルタルの浸透圧発現 にイオンの透過を㧕制しようとする性質が、強く関与していること を示唆するものである。

図-7は、浸透圧の測定を終了後、各モルタル試験体に0.3MPaの水 压を負荷し、透水試験を行った結果を示したものである。透水試験 の結果は、（1）式により試験体の厚さの影響を含んだままの、水 の透過倸数として、整理してある。

$$
\begin{aligned}
& L p=\frac{V}{A \cdot t \cdot P} \\
& \text { ここに、Lp： 水の透過係数 }(\mathrm{cm} / \mathrm{s} \cdot \mathrm{MPa}) \\
& \mathrm{V} \text { : 透水量 }(\mathrm{cm} 3) \\
& \text { A : 試験体の断面積 }\left(\mathrm{cm}^{2}\right) \\
& \text { t：経過時間 ( } \mathrm{sec}) \\
& \mathrm{P} \text { ：負荷水纴 (MPa) }
\end{aligned}
$$

この結果はおおまかには水セメント比が大きいほど、図-1の試験 体の細孔構造の測定結果に示すように、大きい径の細孔量が増加す ること、また試験体の厚さが薄いほど、（2）式のDarcy則で表さ れるように、透水量は試験体の厚さと反比例の関倸にあり、水を透 過させやすくなる。 


$$
\frac{\mathrm{Q}}{\mathrm{A}}=\frac{-\mathrm{K} \cdot \mathrm{P}}{\ell}
$$

ここに、 $\mathrm{K}$ ：透水係数 $(\mathrm{cm} / \mathrm{s})$

$\mathrm{Q}$ ：単位時間当たりの透水量 $(\mathrm{cm} 3 / \mathrm{s})$

$\mathrm{A}$ ：試験体の断面積 $\left(\mathrm{cm}^{2}\right)$

$\mathrm{P}$ ：負荷水压（MPa）

$\ell$ ：試験体の厚さ $(\mathrm{cm})$

これはこれまでの多くの透水性に関する実験結果を追認するもの
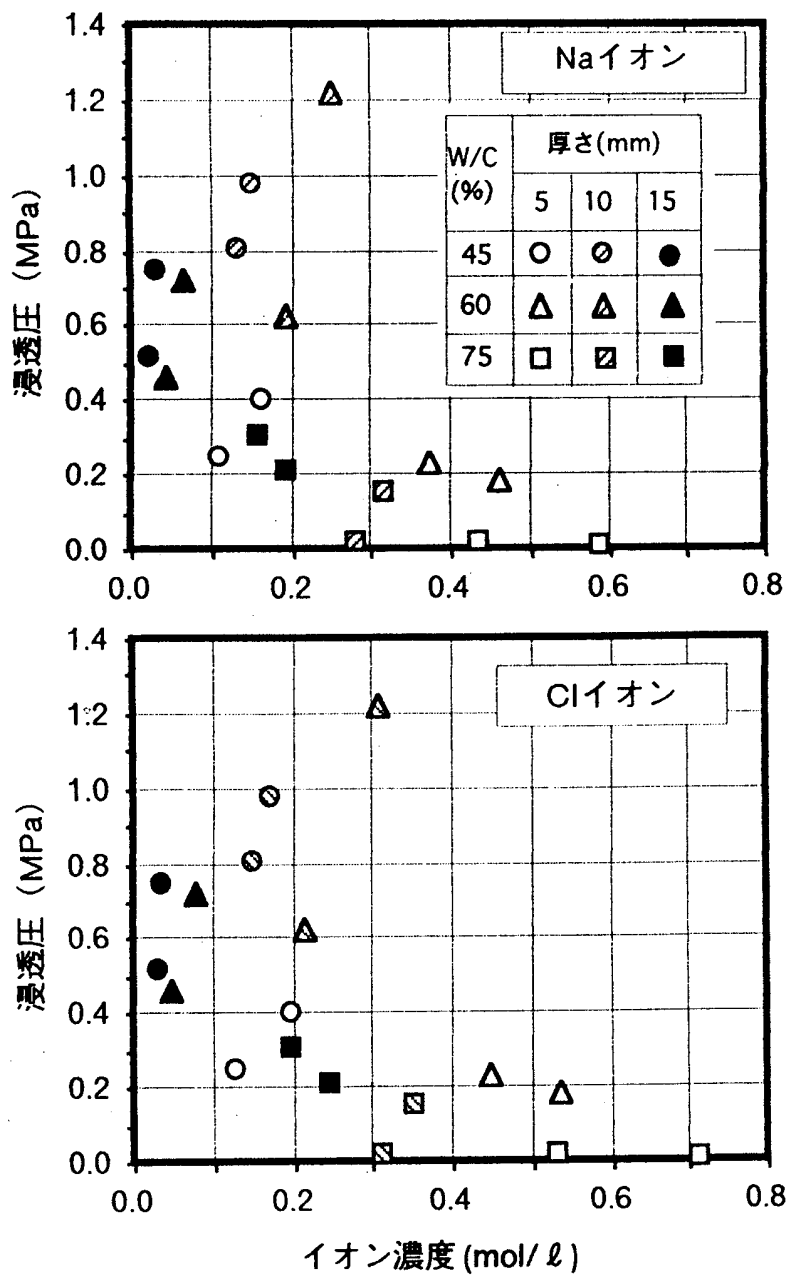

図-6 浸透圧とイオン濃度の関係
であるが、ここでは浸透圧との関係が重要であり、さらに浸透圧と 透水性との関係を調べた。図-8に両者の関係を示す。この図では、 水の透過係数を左加右へ大きくなる順番に並べて表している。こ れによると水の透過係数が $1.00 \times 10^{-6} 6 \mathrm{~cm} / \mathrm{s} \cdot \mathrm{MPa}$ 程度を頂点とし て、それ以上大きい領域、小さい領域のいずれでも浸透压は低下し ている。

水の透過係数の大きい領域での浸透圧の低下は、高まろうとする 圧力が試験体の透過しやすい性質のため漏洩し、压力上昇が緩和さ れるためであり、また透水係数の小さすぎる領域での低い浸透圧 は、II 側圧力容器への水の流入が阻害されるためと推定している。 しかしこれには当然イオンの動きも関与しているはずであり、モル タルを介在しての浸透圧発生は、この両者の複合化しての結果であ ると理解すべきである。そのためにはイオンの挙動についての詳細 な測定が必要とされるが、現状では十分ではなく、その機構の解明 にはさらなる検討が必要である。

\section{5.セメントモルタルの半透過膜的性質の評価}

膜を介して存在する差圧 $\Delta \mathrm{P}$ と浸透圧差 $\Delta \pi$ は、 2 相が平衡状態

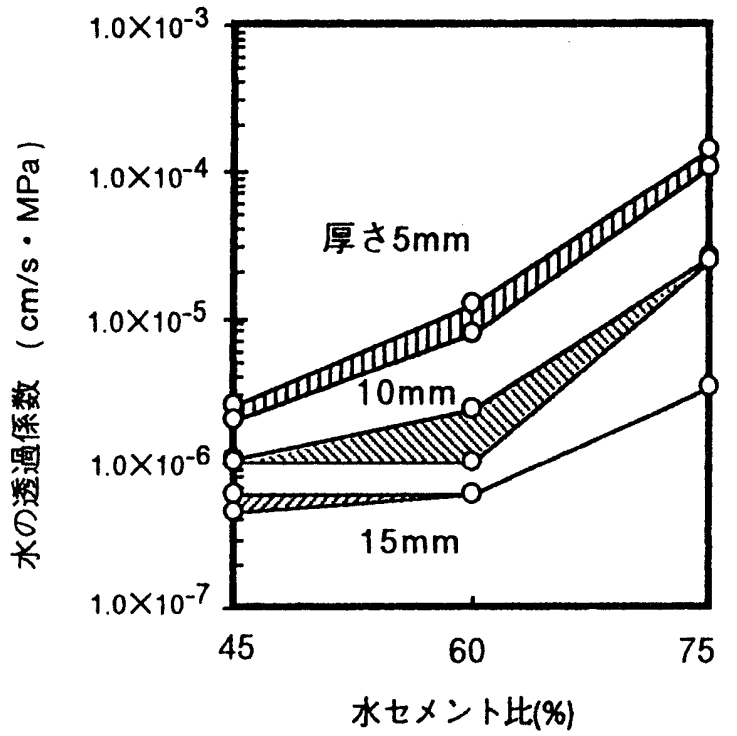

図 -7 水の透過係数の变化

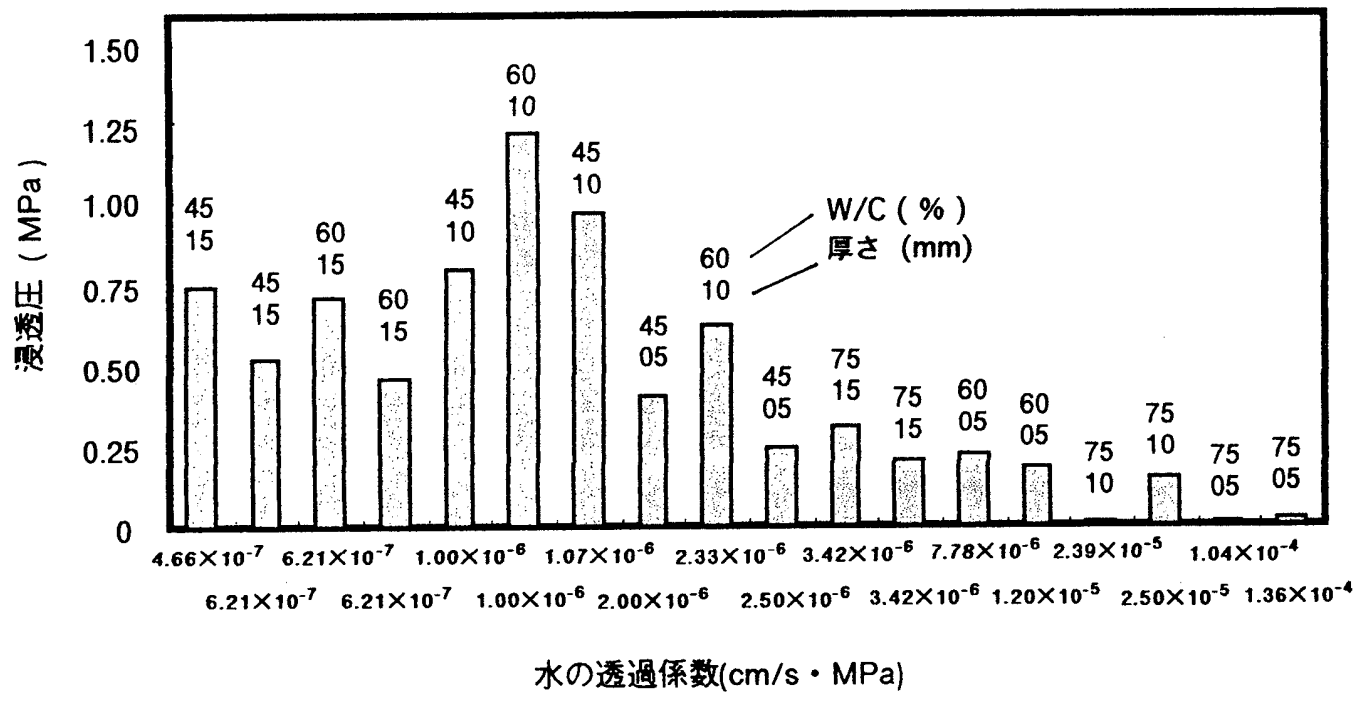

图 - 8 浸透压と水の透過係数の関係 
にある時、

$\Delta \mathrm{P}=\sigma \Delta \pi$

と表される ${ }^{9)}$ 。

ここでのはSta vermanによって定義された反発係数であり、溶質 を完全に通さない膜（完全半透膜）である時 $\sigma=\mathrm{k} 1$ 、自由に通す 膜では、 $\sigma=0$ 、その中間で、膜が溶質の透過に对して幾分か抵 抗となるような膜（不完全半透過膜）では、 $0<\sigma<1$ であり、半

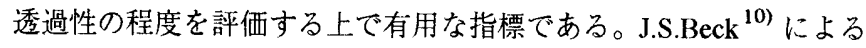
と、ほとんどの膜材料では、完全な半透過性や溶質の完全な自由透 過という極端なことはなく、この中間的挙動を示すと説明されてい る。

$\Delta \pi$ は理論的な浸透圧であり、Van't Hoffの式 ${ }^{11.12)}$ で与えられ、 式（4）で表される。

$$
\Delta \pi=\Delta \mathrm{cRT}
$$

ここに、 $\Delta \mathrm{c}$ : 濃度差 $(\mathrm{mol} / \ell)$

$\mathrm{R}$ : 気体定数 $(\mathrm{J} / \mathrm{K} \cdot \mathrm{mol})$

$\mathrm{T}:$ 絶対温度 $(\mathrm{K})$

本測定では、 $2 \mathrm{~mol} / \ell$ のaCl溶液を用いているので、計算上期待 される浸透圧差 $\Delta \pi$ は $10.134 \mathrm{MPa}$ となる。この值と測定された浸透 圧差を（3）式に代入して、反発係数を計算し、表-2に示す。ここ での測定では測定圧力が最大でも1.2MPaであり、従って反発係数 は0.12であり、中には0.001とかなり小さいものもある。ここでの測 定では半透過膜の性質という観点からは、セメントモルタルはその 調合により変わる、きわめて不完全な半透過性をもつ材料として理 解される。

\section{6. 結論}

セメント硬化体は半透過性を持つとするHanse n ${ }^{5)}$ の立場に立 ち、セメントモルタルを用いて半透過膜的性質を検討した結果をま とめると以下のと抲である。

（1）浸透圧は、モルタルの水セメント比および試験体の厚さの影 響を受ける。それらは水セメント比、厚さとの単調な関係を示さ ず、特定の組み合わせの時に大きな浸透圧が生じる。本赛験の範囲 では、最大 $1.2 \mathrm{MPa}$ の浸透圧が観測された。

（2）浸透圧の発現は、セメントモルタルの水を透過させる性質、 $\mathrm{Na}$ およびClイオンを透過させにくい性質の複合的な作用によると 理解される。

（3）セメントモルタルを半透過膜として評価した時の反発倸数は 小さく、きわめて不完全な半透過膜として理解される。

\section{謝辞}

本研究を行うに当たり、清水建設（株）三原崇明氏（元東京工業 大学大学院) の協力、また清水建設 (株) 技術研究所 橋田 浩氏 の討論を得ました。心より謝意を表します。

\section{参考文献}

(1) P . Kumar Mehta , Paulo J . M . Monteiro : CONCRETE , STRUCTURE, PROPERTIES, AND MATERIALS (Second Edition),PRENTICE HALL,pp.17-113, 1986

（2）羽原俊祐，沢木大介：硬化コンクリートの空隙構造とその物 性, 特集 無機質多孔材料, Gypsum \& Lime No.240, pp.28-

\section{表 - 2 測定圧力および反発係数}

\begin{tabular}{|c|c|c|c|}
\hline $\begin{array}{l}\text { 試験体 } \\
\text { の)厚さ } \\
(\mathrm{mm}) \\
\end{array}$ & $\begin{array}{c}\text { 水セメント比 } \\
(\%)\end{array}$ & $\begin{array}{c}\text { 測定圧力 }(\Delta \mathrm{P}) \\
(\mathrm{MPa}) \\
\end{array}$ & 反発係数 $(\sigma)$ \\
\hline \multirow[t]{6}{*}{5} & \multirow[t]{2}{*}{45} & 0.249 & 0.025 \\
\hline & & 0.402 & 0.040 \\
\hline & \multirow[t]{2}{*}{60} & 0.229 & 0.023 \\
\hline & & 0.180 & 0.018 \\
\hline & \multirow[t]{2}{*}{75} & 0.010 & 0.001 \\
\hline & & 0.022 & 0.002 \\
\hline \multirow[t]{6}{*}{10} & \multirow[t]{2}{*}{45} & 0.803 & 0.079 \\
\hline & & 0.976 & 0.096 \\
\hline & \multirow[t]{2}{*}{60} & 1.218 & 0.120 \\
\hline & & 0.628 & 0.062 \\
\hline & \multirow[t]{2}{*}{75} & 0.016 & 0.002 \\
\hline & & 0.151 & 0.015 \\
\hline \multirow[t]{6}{*}{15} & \multirow[t]{2}{*}{45} & 0.522 & 0.052 \\
\hline & & 0.751 & 0.074 \\
\hline & \multirow[t]{2}{*}{60} & 0.716 & 0.071 \\
\hline & & 0.464 & 0.046 \\
\hline & \multirow[t]{2}{*}{75} & 0.305 & 0.030 \\
\hline & & 0.206 & 0.020 \\
\hline
\end{tabular}

33, 1992

（3）中部セメントコンクリート研究会編：コンクリート 構造物の アルカリ骨材反応（基礎知識・診断方法・防止対策），pp.21 $-23,1991$

（4）中井唯喜，村上信直，平野竜行：塗り床仕上げの標準化に関 する研究 (その 2) 現状での故障状況と対策, 日本建築学会 学術講演梗概集 (A)，pp.103-104, 1988

(5) Hansen,W.C. Studies relating to the mechanics by which the alkailiAggregate Reaction Produces Expansion in Concrete, Journal of the American Concrete Institute, Proceedings Vol.40, pp.213227,January 1944

(6) Duncan McConnell, Richard C.Mielenz, William Y.Holland, Kenneth T.Greene, : Cement-Aggregate Reaction in Concrete, Journal of the American Concrete Institute, Vol.19, No.2, pp.93 -128 , October 1947

(7) W.J.Warlow and P.W.Pye, MRIC: Osmosis as a cause of blistering of in situ resin flooring on wet concrete, Magazine of Concrete Research, Vol.30, No.104, pp.152-156, September 1978

(8) M.Günter, H.K Hilsdorf : Influence of physical and chemical interactions between a concrete substrate and organic surface coatings on bond strength, Durabillity of non-metallic inorganic building materials, pp.161 $-874,1988$

（9）日本化学会編：機能性有機薄膜（化学総説，No.45）講談社; pp. $1-29,1984$

（10）野島庄七：生体膜，東京化学同人, pp.55-57, 1984

（11）荻原文二, 橋本光一編：膜による分離法, pp.125-135, 1988

（12）大木道則, 大沢利昭, 田中元治, 千原秀昭編：化学大辞典, 東京化学同人, p.1159, 1989

（1996年10月 9 日原稿受理，1996年12月17日採用決定） 